\title{
Financiamento da política de assistência social: avanços e perspectivas
}

\author{
Financing of social assistance policy: advances and perspectives \\ LUANA PASSOS (1) 1 \\ ANDREIA ANDRADE DOS SANTOS (1) ${ }^{2}$ \\ ALAN SCARPARI (10 ${ }^{3}$ \\ ${ }^{1}$ Universidade Federal de Minas Gerais, Belo Horizonte, MG, Brasil. \\ ${ }^{2}$ Universidade Federal da Bahia, Salvador, BA, Brasil. \\ ${ }^{3}$ Ministério da Agricultura, Pecuária e Abastecimento, Brasília, DF, Brasil.
}

RESUMO - Esse artigo objetiva fazer um panorama do financiamento da política de assistência social, apresentando as mudanças normativas, o aporte orçamentário e as perspectivas. Como metodologia, acessou-se o levantamento da produção normativa do órgão gestor da política, que pode ser solicitado aos autores, e a análise descritiva dos dados extraídos do Painel de Orçamento Federal, do atual Ministério da Economia ${ }^{1}$, que são oriundos do Sistema Integrado de Administração Financeira do Governo Federal (SIAFI), sistema que realiza toda a execução orçamentária e financeira do governo federal. Os resultados apontam para mudanças, com base nas orientações da Política Nacional de Assistência Social (PNAS) e da Norma Operacional Básica (NOBs/SUAS), que propiciaram um novo padrão de financiamento, com adensamento da institucionalidade, maior abrangência territorial e populacional e ampliação do escopo protetivo da política. O trajeto orçamentário foi ascendente, saindo de um patamar de 0,9\% do Produto Interno Bruto (PIB), em 2006, para 1,3\%, em 2018. As perspectivas, porém, não são nada animadoras, tendo em vista o cenário de congelamento, em termos reais, da despesa primária da União e um fortalecimento da concepção de assistência social como caridade e benemerência.

Palavras-chave: Financiamento. Assistência social. PNAS. NOB/SUAS. Gasto federal.

ABSTRACT - This article aims to give an overview of the financing of social assistance policy, presenting the normative changes, the budget contribution, and the perspectives. As a methodology, it was accessed the survey of the normative production of the policy management body, which can be requested from the authors, and the descriptive analysis of the data extracted from the Federal Budget Panel of the current Ministry of Economy, which come from the Integrated System of Financial Administration of the Federal Government (SIAFI), system that performs all the budgetary and financial execution of the federal government. The results point to changes, based on the guidelines of the National Social Assistance Policy (PNAS) and the Basic Operational Standard (NOBs / SUAS), which provided a new standard of financing, with a broader institutional and territorial scope and expansion of the policy's protective scope. The budget line went up from $0.9 \%$ of gross domestic product (GDP) in 2006 to $1.3 \%$ in 2018. The outlook, however, is not encouraging, considering the scenario of freezing the Union's primary expenditure in real terms and strengthening the concept of social assistance as charity and benevolence.

Keywords: Financing. Social assistance. PNAS. NOB/SUAS. Federal spending. 


\section{Introdução}

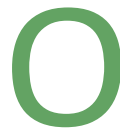

estabelecimento, na Constituição de 1988, da assistência social como componente da Seguridade Social demandou um redesenho das ações, dos conjuntos de aportes financeiros e da própria concepção, de caridade e benemerência, que de longa data orientaram a atuação na área. A Carta Magna de 1988 delineou um novo paradigma para a assistência social, transitando a área para o campo do direito e como componente de um sistema de proteção que se propõe a ser universal no acesso e de primazia estatal.

O novo paradigma da assistência social foi consolidado por normatizações, tendo como principais referências: a Lei Orgânica da Assistência Social (LOAS); a Política Nacional de Assistência Social (PNAS); a Norma Operacional Básica (NOB), que regulamentou o Sistema Único de Assistência Social (SUAS); e a Lei do SUAS, que acolheu o SUAS na LOAS. A trajetória seguida levou ao adensamento da institucionalidade, em um notório esforço governamental de consolidar uma política nacional.

Em conformidade com a instituição da assistência social como uma política pública, foram presenciadas mudanças expressivas no financiamento das ações. Um novo padrão de financiamento foi instituído, possibilitando a construção e a efetivação de um sistema integrado, participativo e territorializado, de modo diametralmente oposto às ações segmentadas e fragmentadas que tradicionalmente eram operadas no âmbito da assistência social.

Após longo percurso com diminuto compromisso estatal no financiamento da área, hoje as três instâncias governamentais se comprometem a aportar recursos e prover uma oferta socioprotetiva em todo o território nacional. Com orientação de promoção de programas, projetos e serviços de modo continuado, e em conformidade com as diversidades regionais, o financiamento passou a ser operado por pisos de proteção social, rompendo a lógica per capita que outrora imperava. Pouco a pouco, normatizações deram a tônica desse novo padrão de financiamento, com destaque para as orientações da PNAS e das NOB/SUAS 2005 e 2012.

Em conformidade com a concretização da assistência social como direito de cidadania, houve um crescimento expressivo do gasto público federal, saindo de um patamar de R\$21,6 bilhões, em 2006, para $\mathrm{R} \$ \mathbf{8 8 , 7}$ bilhões, em $2018^{2}$. Todavia, o cenário futuro do financiamento da assistência social é incerto, dado o estabelecimento de um teto para as despesas primárias da União, pela Emenda Constitucional 95, e o avanço de uma onda conservadora no País.

Posto isso, este artigo objetiva traçar um panorama do financiamento da política de assistência social, apresentando as mudanças normativas, a evolução orçamentária e as perspectivas para a área.

$\mathrm{O}$ artigo está dividido em três seções além desta introdução e das considerações finais. A primeira seção se propõe a discutir as mudanças operadas no financiamento, em conformidade com as orientações da PNAS e as diretrizes das NOBs/SUAS. Na segunda seção é apresentada a evolução recente do gasto público federal com a política de assistência social. A terceira seção se dedica a debater perspectivas para área da assistência social frente à Emenda 95 e apresenta fatores que demonstram o avanço de uma onda conservadora na sociedade.

\section{Padrão de financiamento da Assistência Social: diretrizes da PNAS e NOBs}

\subsection{Orientações da PNAS}

Em que pese a Constituição de 1988 estabelecer a assistência social como direito de cidadania, até os anos 2000 a área não tinha proeminência no rol das políticas públicas. 0 aporte financeiro público era pouco expressivo, o que ocasionava uma oferta residual e debilitada.

A marginalização da área assistencial pelo poder público começa a ser rompida com a promulgação da LOAS, em 1993, e mais enfaticamente com a aprovação pelo Conselho Nacional de Assistência Social (CNAS) da Política Nacional de Assistência Social (PNAS), em 2004. 
A PNAS prevê um padrão de financiamento que rompe com o modelo centralizado e a lógica genérica até então atuantes, de modo a enfrentar a marca da área, que era uma oferta pontual e sem o apropriado amparo às famílias pelo Estado. Assim, com a PNAS um novo mecanismo de repasse financeiro passa a ser operacionalizado, deslocando o foco do público atendido para serviço a ser estruturado no território. Esse novo conceito de repasse de recursos quebra antigos empasses para a efetivação das ações assistenciais, tais como a pouca previsibilidade de recursos e de planejamento do acompanhamento das famílias que outrora imperava.

A PNAS previa para área assistencial um sistema descentralizado e participativo, operado por meio de um Sistema Único atuando em todo território nacional. A instância onde se daria o financiamento seria o Fundo de Assistência Social, que deveria se fazer presente nas três esferas governamentais.

O Fundo Nacional de Assistência Social foi instituído na LOAS, sendo regulamentado pelo Decreto no 1605/95. Conforme esse decreto, os fundos teriam por finalidade o estabelecimento de recursos e mecanismos de financiamento do Benefício de Prestação Continuada e dos demais serviços, programas e projetos da área assistencial.

Como forma de endossar a descentralização da área assistencial, a PNAS, de modo claro, advoga que o financiamento das ações assistências deve respeitar às instâncias de gestão compartilhada e de deliberação da política. Em uma responsabilidade compartilhada, o financiamento dos benefícios seria repassado de forma direta pelo governo federal aos seus destinatários, e o financiamento da rede socioassistencial se faria através de recursos próprios e dos recursos transferidos fundo a fundo, em conformidade com os critérios de elegibilidade e partilha pactuados nas comissões intergestores e deliberados nos conselhos de assistência social.

Para a consolidação de uma responsabilidade compartilhada, a PNAS orienta que a rede assistencial deve contar com recursos dos três entes federados, de modo a afiançar uma concreta proteção social universal. Essa proteção deveria ocorrer conforme as peculiaridades e necessidades da população vulnerável, prevendo a PNAS que o financiamento da política assistencial deveria ser orientado pelos diagnósticos socioterritoriais.

Era perceptível na PNAS o esforço de consolidar o pacto federativo brasileiro na área assistencial. Nessa direção, essa Política representou um notório avanço no estabelecimento do cofinanciamento entre os três entes federados. O cofinanciamento visa a atender a demanda do SUAS de uma oferta pública continuada, descentralizada e universal, sendo premente contar com repasse financeiro que não sofresse descontinuidade. Para Tavares (2013), o desafio posto era superar a forma tradicional, operada sob a lógica da série histórica, em prol de repasses regulares que possibilitassem às esferas locais atenderem as demandas da população destinatária.

O estabelecimento do cofinanciamento pelas três esferas do governo comparece como inovação relevante, propiciando critérios mais equitativos e o fortalecimento do arranjo federativo na construção do SUAS. Todavia, o cofinanciamento se refere primordialmente ao custeio dos serviços, dado que os benefícios monetários, de modo geral, são pagos diretamente às famílias.

A PNAS estabelece que o financiamento deva ocorrer em conformidade com os pisos de atenção, em observância aos níveis de complexidade da política. Assim, a transferência de recursos deveria ser operacionalizada pensando nas demandas presentes no nível da Proteção Social Básica (PSB) e da Proteção Social Especial (PSE).

Outro elemento destacado na PNAS é a necessidade de revisão dos instrumentos de planejamento público, com ênfase para o Plano Plurianual. Pela PNAS, a revisão desses instrumentos tem o intuito de colocar em relevo a necessidade de não ruptura radical com o que estava em vigência na área, de modo a garantir a continuidade no atendimento ofertado aos usuários.

Dado que uma linha tênue sempre delineava os contornos entre atuação da área assistencial e de outras políticas públicas, a PNAS previu negociação e assinatura de protocolos intersetoriais com a saúde e a educação, de modo a permitir a transição do financiamento dos serviços afetos a essas áreas, que até o momento estavam sendo executados no âmbito da assistência. 
A PNAS também aborda uma reivindicação que até hoje é pauta na área assistencial - vinculação constitucional de, no mínimo, $5 \%$ do orçamento da Seguridade Social. Conforme as discussões e deliberações da IV Conferência Nacional de Assistência Social, de que a vinculação de $5 \%$ no âmbito federal em relação ao orçamento da Seguridade Social fosse calculada exclusive do BPC, a PNAS orienta, enquanto não se efetiva essa conquista federal, que os estados, o Distrito Federal e os municípios tenham um investimento de no mínimo $5 \%$ do total de arrecadação de seus orçamentos para a área. Há que se destacar, porém, que não se têm dados para atestar em que medida estados e Distrito Federal acomodam essa orientação.

\subsection{Orientações da NOB/SUAS 2005 e NOB/SUAS 2012}

A PNAS pode ser considerada um instrumento basilar de orientação para a nova concepção da assistência social. Todavia, essa nova concepção prescindia de uma norma que orientasse sua operacionalização, o que foi feito pela Norma Operacional Básica do SUAS - NOB/SUAS aprovada pela Resolução CNAS n. 130, de 15 de julho de 2005.

A NOB/SUAS comporta um amplo leque de elementos imprescindíveis para implantação e consolidação do SUAS, tais como: as competências da política de assistência social enquanto política pública; a rede protetiva que deve ser afiançada no SUAS; o compartilhamento de responsabilidades entre os entes federados na oferta dos serviços; os mecanismos de planejamento e financiamento; e as instâncias de articulação, pactuação e deliberação. Contudo, muito da relevância da NOB/SUAS para consolidação da assistência social enquanto política pública se deve à regulamentação dos mecanismos de gestão e dos instrumentos para o planejamento financeiro dos três entes governamentais que, de longa data, erguiam entraves ao avanço da área.

Na nova sistemática de financiamento, a NOB/SUAS comportava critérios para a promoção de compartilhamento mais equitativo de recursos federais para os estados, Distrito Federal (DF) e municípios, como preconizado na LOAS. O intuito dessa nova sistemática era promover uma proteção ampla. Para tanto, a repartição de recursos deveria se pautar nas diversidades regionais e nas demandas específicas dos territórios.

A mudança na forma de financiamento almejava afiançar uma oferta socioprotetiva que resguardasse a população de um amplo leque de vulnerabilidades socioeconômicas. $\mathrm{O}$ alcance desse objetivo demandava não apenas o compartilhamento de responsabilidades entre os entes federados no financiamento da política, mas também o aprimoramento da gestão financeira. Como aponta Tavares (2013), financiamento e gestão são dois pilares de sustentação de toda e qualquer política, sendo imperativo o avanço concomitante para o enfrentamento do cenário da precariedade e das dificuldades enfrentadas pela assistência social na sua concretização como política pública.

No que se refere à gestão financeira, o novo padrão de financiamento concede relevo aos fundos de assistência social como mecanismos fundamentais no financiamento da política, em consonância com a determinação da Constituição Federal de 1988. Os fundos financeiros são tidos como fundos especiais, nos quais, conforme a Lei 4.320/64, devem ser reunidos recursos financeiros para determinadas ações referentes a essa política.

Os fundos de assistência social se estruturam como unidades orçamentárias, em que se devem alocar todos os recursos demandados para execução das ações, serviços e benefícios socioassistenciais.

A operacionalização dos recursos por fundos possibilitou avultados avanços no financiamento da política, facilitando a concretização dos objetivos preconizados na PNAS. Com os fundos, o financiamento da área passa a contar com: repasse regular e automático; simplificação dos processos de trabalho; aprimoramento do controle e avaliação dos serviços e ações; aperfeiçoamento dos modos de comprovação dos gastos, entre outros avanços.

Os fundos de assistência social comparecem como requisito imperativo para financiamento da política, uma vez que a estruturação e o funcionamento do fundo de assistência social nos estados, DF, e municípios são exigências para repasses de recursos federais. Conforme previsto na NOB, cada esfera governamental 
deve destinar recursos próprios para o financiamento de ações na área, sendo, portanto, por meio dos fundos que se operacionaliza o cofinanciamento da política assistencial. Claramente, a compulsoriedade de aportes financeiros dos três entes federados presta uma contribuição avultada para a concretização da oferta socioprotetiva e para a materialização de uma responsabilidade federativa na consolidação do Sistema Único da Assistência Social.

Em que pese os avanços no financiamento da assistência social dada a implantação dos fundos, ainda há conquistas a serem efetivadas, em especial no nível estadual e municipal. Como apontam Mesquita, Martins e Cruz (2012), os fundos encontram dificuldades para reunir todos os recursos financeiros destinados à política de assistência social nos estados e municípios.

Em conformidade com o preconizado no inciso IX do art. 18 da LOAS, o CNAS deverá aprovar os critérios de partilha e transferências de recursos observando indicadores que abarquem as escalas territoriais e as diversidades regionais, tais como: informações sociais, econômicas, demográficas e cadastrais.

Em que se pese às dificuldades de operar uma metodologia objetiva na partilha e distribuição dos recursos, a NOB prima por um acordo de critérios de divisão e de pactuação de resultados e metas que se ancorem na equalização, priorização e projete a universalização no percurso da PNAS.

A despeito da autonomia que goza os entes da federação, a orientação é que a repartição dos recursos no âmbito das esferas subnacionais também seja realizada de modo a afiançar a equidade preconizado na LOAS e na PNAS. Todavia, Mesquita, Martins e Cruz (2012) chamam atenção para a ausência de informações sistematizadas que possibilitem avaliar em que medida os estados e municípios têm seguido a partilha de recursos previstos na NOB.

Ao passo que a partilha financeira foi pautada em uma miríade de indicadores sociais e territoriais, os critérios de transferências foram guiados por Pisos de Proteção Social. Os pisos como modalidade de transferência de recursos devem ser adotados pelos três entes federados, em conformidade com o compromisso de compartilhamento de responsabilidades na construção da política assistencial.

Os Pisos estabelecidos, em sintonia com os níveis de complexidade abarcados no SUAS, são os seguintes: Piso Básico Fixo; Piso Básico de Transição; Piso Básico Variável; Piso de Transição de Média Complexidade; Piso Fixo da Média Complexidade; e Pisos de Proteção Social Especial de Alta Complexidade I e II.

Em suma, os pisos são organizados por nível de complexidade dos serviços, sendo três pisos componentes na PSB e cinco na PSE. No que se refere ao formato, a NOB/SUAS diferenciou os pisos entre "fixo" e "variável". Os pisos fixos operam na estruturação dos serviços, notadamente nos equipamentos públicos Cras e Creas. Os pisos variáveis visam atender situações dinâmicas e diversidades socioterritoriais que influenciem na estruturação dos serviços. Essa diferença se assenta na necessidade de conceder flexibilidade no padrão de financiamento, de modo a atender demandas complexas.

Os recursos do cofinanciamento do Programa de Erradicação do Trabalho Infantil (PETI) não seguiram a forma de pisos, dada a amplitude do pacto internacional referente ao enfrentamento do trabalho infantil, seguindo o repasse financeiro de acordo com as regras específicas do PETI.

A despeito das dificuldades ainda encontradas para concretizar o cofinanciamento por meio dos pisos, como aponta Colin (2008), a mera instituição de pisos já proporcionou um aumento considerável do cofinanciamento federal.

A proposta de cofinanciamento entre os entes federados comparece como elemento basilar no novo padrão de financiamento da política de assistência social. Com essa proposta, de forma clara, se estabelece o compartilhamento de competências entre as esferas do governo de modo a garantir uma gestão da política assistencial em todo território nacional.

Não obstante, o desafio posto para a consolidação do cofinanciamento é a conciliação da proposta de partilha de competências financeiras na área da assistência social com o orçamento público das três esferas governamentais. Logo, a efetivação do cofinanciamento passa pelo estabelecimento de pactuações entre as esferas do governo, de modo a firmar o compromisso, as competências e as atribuições no que concerne aos aportes orçamentários e financeiros demandados para a concretização da política de assistência preconizada na PNAS. 
A NOB/SUAS 2005 se baseava na adesão dos entes ao sistema, por meio da habilitação dos municípios a um dos níveis de gestão do SUAS (inicial, básica ou plena), e no acordo de aprimoramento da gestão com os estados. Para aperfeiçoar o funcionamento do SUAS, foi criada a NOB/SUAS 2012, que modificou a gestão federativa do SUAS, estabelecendo uma nova proposta de gestão descentralizada com essência na substituição da adesão, por meio do processo de habilitação, pelos vínculos de pactuação de prioridades entre os entes.

Com a NOB/SUAS 2012 houve a consolidação de mudanças outrora realizadas, tais como: a criação dos incentivos financeiros à gestão (IGD-SUAS e IGD-PBF); o Censo SUAS; a Norma Operacional Básica de Recursos Humanos (NOB/RH); o Protocolo de Gestão Integrada dos Serviços, Benefícios e Transferência de Renda; a Tipificação Nacional dos Serviços, entre outras.

A NOB/2012 reforça o compromisso do SUAS em promover uma oferta compatível com as necessidades do território nacional. Para tanto, estabelece que a oferta protetiva deve se pautar no diagnóstico das necessidades e especificidades locais e regionais conforme cruzamento de informações e indicadores sociais. Ademais, é um orientador da NOB/SUAS 2012 promover a equalização e universalização da cobertura em conformidade com os planejamentos intraurbanos.

$\mathrm{Na}$ Proteção Social Básica, a NOB/2012 definiu que a partilha deveria ser feita com base: no quantitativo de famílias presentes no município ou DF (mediante os dados populacionais do IBGE); no quantitativo de famílias existentes no cadastro único; na extensão territorial; nas peculiaridades locais ou regionais; na cobertura de vulnerabilidades conforme ciclo de vida e demais indicadores que fossem pactuados na Comissão Intergestores Tripartite (CIT).

A NOB/2012 avançou na definição de critérios de partilha financeira para PSE, dado que com essa norma a partilha de recursos na PSE passou a ser conforme as situações de risco pessoal e social. Atento as violações de direitos, se elaborariam parâmetros e teto para o repasse de recursos do cofinanciamento que atendessem a estruturação de uma rede suficiente para operacionalizar os serviços demandados na realidade daquele território. Essa norma prevê uma oferta particularizada na Proteção Social Especial, com diversidade nas unidades que ofertam os serviços, de modo a atender a variedade de vulnerabilidades que marcam um país continental como o Brasil.

Na partilha de recursos, a novidade dessa NOB foi a introdução de critérios de partilha de cofinanciamento da gestão. Essa NOB estabelece cálculo de indicadores pactuados nas instâncias deliberativas, CIT e CNAS, com intuito de avaliar a qualidade da gestão e premiar os gestores locais de acordo com o desempenho de sua gestão. Com o estabelecimento do Índice de Gestão Descentralizada (IGD), a partilha de cofinanciamento da gestão passa, então, a ser distinta da lógica operada no cofinanciamento dos serviços.

O incentivo à gestão descentralizada do SUAS se dará mediante o Índice de Gestão Descentralizada Estadual do Sistema Único de Assistência Social-IGDSUAS-E, e o Índice de Gestão Descentralizada Municipal do Sistema Único de Assistência Social-IGDSUAS-M. A norma prevê incentivo à gestão do Bolsa Família, por meio do Índice de Gestão Descentralizada Estadual do Programa Bolsa Família-IGD PBF-E e do Índice de Gestão Descentralizada Municipal do Programa Bolsa Família- IGD PBF-M.

O incentivo à gestão descentralizada tem por intuito apoiar financeiramente os processos de gestão e prestação de serviços, programas, projetos e benefícios socioassistenciais a nível local e regional. Também procura incrementar o processo de gestão do PBF e do cadastro único nas esferas municipais, estaduais e Distrito Federal. O movimento por trás desses incentivos, conforme Mesquita, Martins e Cruz (2012), parece ter sido o aprimoramento do arranjo federativo tanto na gestão do programa de transferência de renda como em outras dimensões da política de assistência social.

No cofinanciamento, a NOB 2012 apresenta um proeminente avanço, tendo em vista a riqueza de detalhes concernente à temática. Muitas das diretrizes já constavam na NOB 2005, mas a forma com que foi apresentada na NOB 2012 facilita a compreensão das responsabilidades a cargo de cada ente governamental.

Como pressupostos para o cofinanciamento da gestão compartilhada, a NOB 2012 destacou: i) a definição e o cumprimento das responsabilidades dos entes federados; ii) a participação orçamentária e financeira de todos os entes governamentais; iii) a implantação e implementação das transferências de recursos, de modo automático, na modalidade fundo a fundo; iv) o financiamento continuado de benefícios 
e serviços constantes na tipificação nacional; v) a definição de pisos para os serviços assistenciais e incentivos à gestão; vi) critérios transparentes de partilha de recursos; e vii) financiamento de programas e projetos.

Uma novidade da NOB 2012 foi a definição das responsabilidades que estados, municípios e Distrito Federal deveriam afiançar com recursos próprios. Cabe destacar algumas dessas responsabilidades: custeio dos benefícios eventuais ${ }^{3}$; atendimento às situações de emergência; provimento da infraestrutura que se fizer necessária para a execução das atividades do Conselho de Assistência Social. No caso da União, a novidade é a inclusão da responsabilidade de financiamento do Programa Bolsa Família (PBF).

De modo a facilitar a execução do financiamento, foi previsto na NOB 2012, o conceito de blocos de financiamento. Os blocos de financiamento representam a reunião de recursos previstos aos serviços, programas e projetos, tipificados nacionalmente, e gestão financeira, de modo a conceder maior liberdade ao gasto do recurso no mesmo nível de proteção. Em outras palavras, os blocos de financiamento se destinam a cofinanciar as ações componentes da Proteção Social Básica e Especial, a gestão do SUAS e a gestão do Bolsa Família e do cadastro único.

Os recursos componentes de cada bloco de financiamento só podem ser aplicados nas ações e serviços referentes àquele bloco, inclusive gastos em investimento e custeio em equipamentos públicos. $\mathrm{A}$ NOB previa que questões referentes à operacionalização do cofinanciamento por blocos de financiamento seriam objeto de regulamentação específica ${ }^{4}$.

\section{Gasto público na política de assistência social: um olhar sobre o período recente}

O gasto social é insistentemente colocado em xeque na sociedade brasileira, especialmente em momentos de crises econômicas e restrições fiscais, como o País vive atualmente. O orçamento público brasileiro vem sofrendo com constantes modificações e as discussões que existem demonstram as divergências sobre a importância do direcionamento do gasto público para o social. Muitas vezes vêm ao centro da discussão a eficiência, eficácia e efetividade dos programas e da dimensão do financiamento despendido.

Em sociedades capitalistas, a disputa pelo fundo público é recorrente, sendo o orçamento público um espaço de luta política e de interesses antagônicos entre as distintas classes sociais. Para Salvador (2012), o orçamento público é um elemento importante da política social, pois representa, além de uma peça técnica da estruturação contábil, a correlação de forças sociais que estabelece quem vai arcar com o ônus do financiamento dos gastos orçamentários.

Em um cenário de financeirização da economia, as pressões sobre a política social, em especial as instituições da Seguridade Social, se exacerbam, na medida em que se acentua a disputa pelo fundo público por parte do capital privado rentista. Desde a crise do capital, em 2008, a apropriação do fundo público pelo capital portador de juros vem ganhando proporções acentuadas, com notórios reflexos na redução de direitos sociais quando acoplada as políticas de austeridade fiscal que têm levado a fortes cortes no orçamento estatal (MENDES, 2014). As diversas frações do capital, com destaque para o capital portador de juros, tem sido capaz de capturar o Estado, estabelecendo uma hegemonia via apropriação do fundo público e a definição nas políticas sociais que são prioritárias (RIBEIRO; SALVADOR, 2018). Mesmo após 30 anos da Constituição Cidadã, no Brasil, não houve uma agenda comum em prol da concretização do conceito da Seguridade Social, estando as políticas sociais marcadas pelo corte de recursos e por uma disputa orçamentária confinada à prioridade de gastos compulsórios (SPOSATI, 2018).

Mediante esse cenário de financeirização da economia e perda de espaço no fundo público para a área social, nesta seção será abordada a evolução do financiamento da política de assistência para o período de 2006 a 2018, uma política deveras relevante em um país com acentuado nível de pobreza e desigualdade como o Brasil. Ressalta-se que é de grande dificuldade uma análise do arcabouço orçamentário brasileiro, que em si já é complexo por causa das divergências quanto a composição do gasto público e ao seu próprio significado econômico. O objetivo é fazer uma análise da despesa, buscando-se compreender a magnitude e a composição do gasto social brasileiro na área da assistência, essencialmente no âmbito da União5. 
A partir dos anos 2000, os gastos com assistência social foram classificados na função 8 , com as seguintes subáreas: Assistência ao idoso, Assistência ao portador com deficiência, Assistência à criança e ao adolescente e Assistência comunitária. A maior parte das ações passou a se enquadrar nesta última subfunção. Essa classificação discricionária gerou algumas limitações às análises e à avaliação dos gastos com assistência social, pois alguns indicadores passaram a ser classificados como saúde e educação para cumprir as metas nessas áreas.

Essa classificação, que foi estabelecida na portaria no 42/1999, tornou obrigatória a sua utilização pelos entes federados. No âmbito federal, essa restrição foi suplantada, pois acompanhou os avanços normativos requeridos pela PNAS (2004) e NOB/Suas (2005;2012). Em 2002, por exemplo, a função 8 abarcava o gasto do Ministério da Previdência e da Assistência Social (MPAS), além de gastos de outros ministérios. Já a partir de 2004, esta função vai passando a se concentrar no orçamento do Ministério do Desenvolvimento Social (MDS) e vai sendo reduzida a sua utilização por outros ministérios. Desde 2006, a função 8 se tornou exclusiva do gestor nacional da política de assistência social (MESQUITA; MARTINS; CRUZ, 2012), sendo a partir desse ano que se centra a análise.

Após longo curso de parcos investimentos na área assistencial, presenciou-se, no período de $2006 \mathrm{e}$ 2018, um aumento real de 46, 6 bilhões no orçamento federal da área, como pode ser visto no Gráfico 1. Em termos reais, o orçamento alocado na função 8 teve toda a trajetória ascendente. Até mesmo nos anos de 2017 e 2018, onde já vigora a Emenda 95 - teto das despesas primárias - foi observado um aumento desse orçamento específico.

Gráfico 1 - Evolução da Execução Orçamentária da União na Assistência Social (Função 8), Brasil, 2006-2018

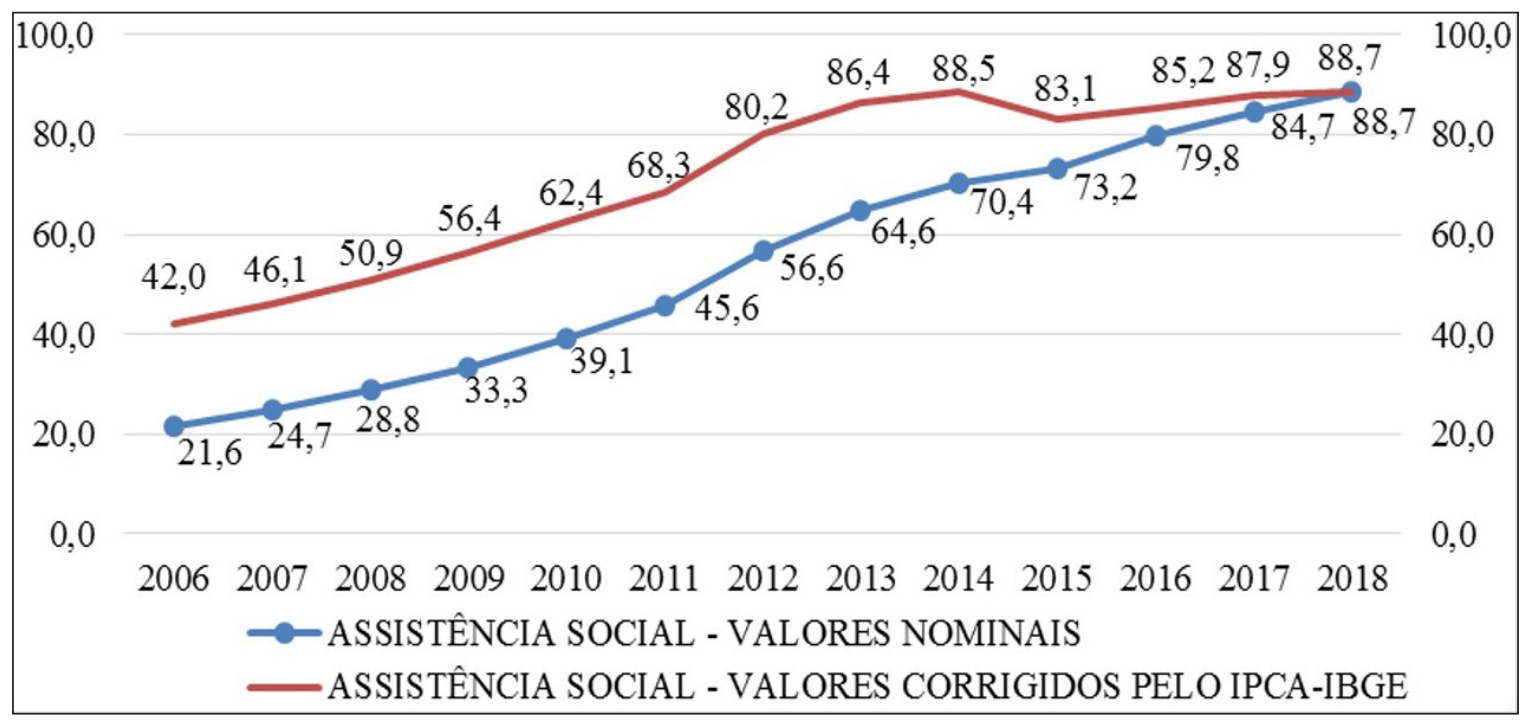

Fonte: Elaboração própria com base em SIAFI, 2006-2018.

As expectativas iniciais eram de que o orçamento da área assistencial fosse reduzido pós-2016, devido à Emenda 95, mas, por enquanto, não se observa o fato. Essa elevação orçamentária, ao contrário do que era esperado, é de se comemorar, ainda mais considerando a crise econômica, que lançou um expressivo contingente populacional no desemprego, passando a demandar apoio da política de assistência social.

Resta saber: qual será a tônica do governo Bolsonaro? Como será abordado na próxima seção, o governo Bolsonaro já faz propostas para enxugar a proteção socioassistencial, com discurso de organização das contas públicas e melhor eficiência do Estado. 
Gráfico 2 - Representação da Assistência Social em Relação ao PIB, Brasil, 2006-2018

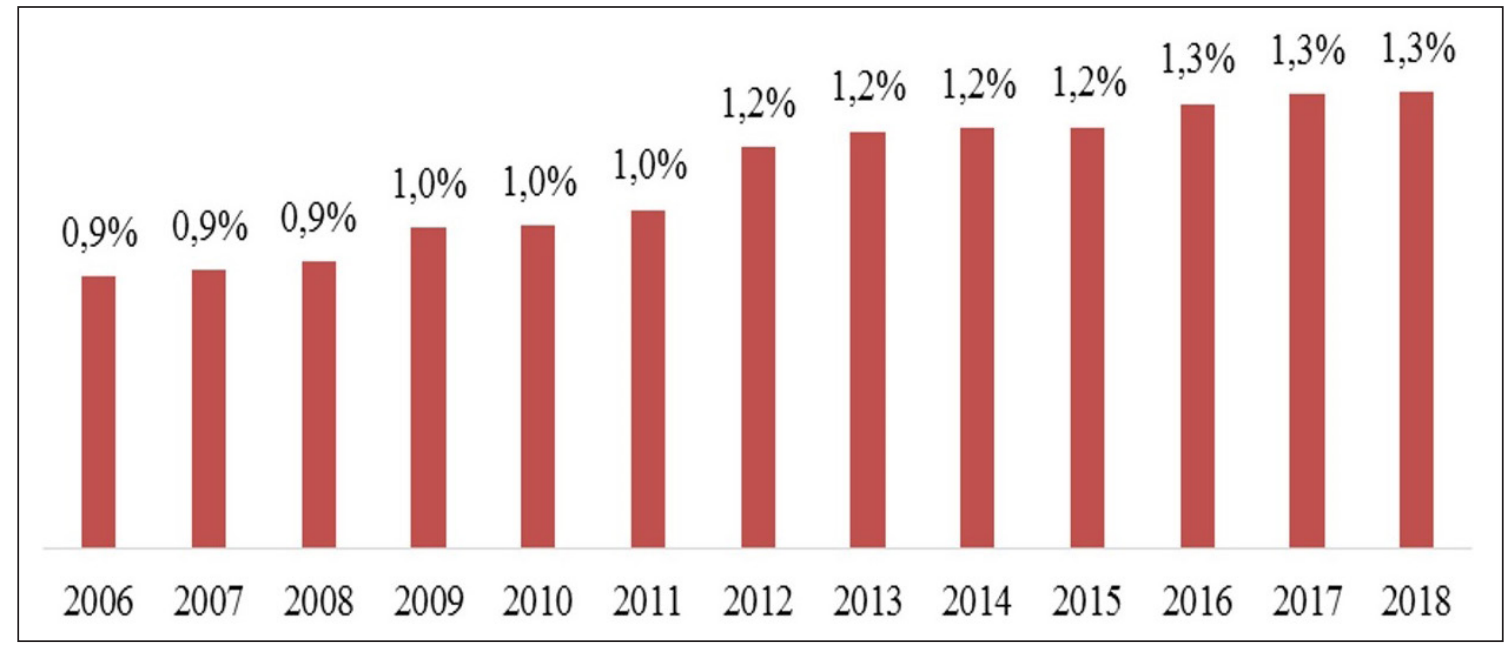

Fonte: Elaboração própria com base em SIAFI, 2006-2018.

Quanto à representação do gasto com Assistência Social em relação ao PIB do Brasil, nota-se um aumento de 0,4 ponto percentual no período em análise, conforme demonstrado no Gráfico 2 . 0 gasto com assistência social, em termos de PIB, saiu de um patamar de 0,9\%, em 2006, para 1,3\%, em 2018, o que, embora pareça pouco, não é desprezível.

Quando se observa o gasto da assistência social em relação ao gasto total da União, Gráfico 3, e em relação ao orçamento da Seguridade Social, Gráfico 4, o valor não é tão destacado, o que deixa claro que, apesar dos avanços, gasta-se pouco com essa área, em especial considerando a magnitude da pobreza no País. Conforme o IBGE (2018), por volta de um quarto da população brasileira $(26,5 \%)$ está abaixo do limiar da pobreza pela linha do Banco Mundial, US\$ 5,50 por dia por pessoa, em valores de 2011.

Gráfico 3 - Representação da Função Assistência Social em Relação ao Orçamento da União, Brasil, 2006-2018

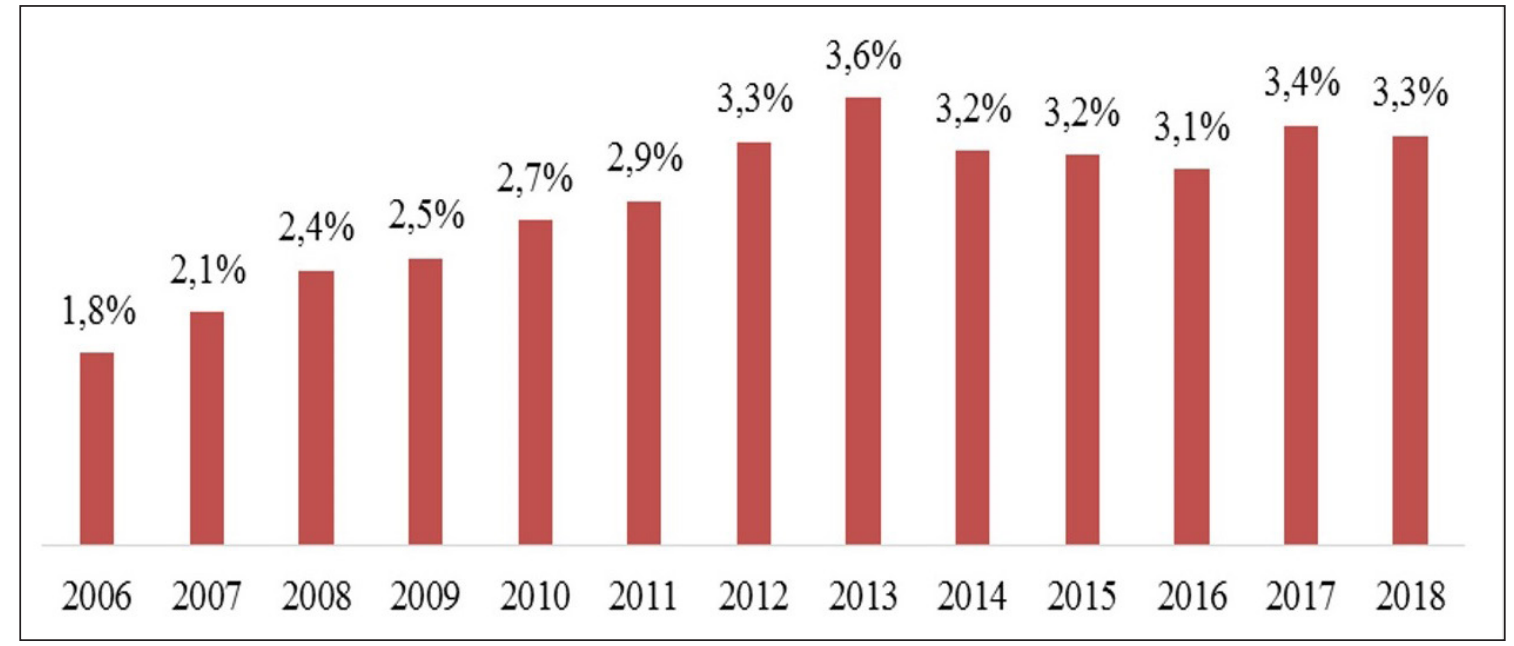

Fonte: Elaboração própria com base em SIAFI, 2006-2018. 
O gasto com assistência social em relação ao orçamento da União saiu de um patamar de 1,8\%, em 2006, para 3,3\%, em 2018. Apesar disso, com um contingente tão expressivo de pobres, ainda é imprescindível um maior aporte orçamentário para a política de assistência social, de modo a afiançar cidadania para aqueles que, com a renda de mercado, não são capazes de alçar uma vida digna. A demanda por ações assistenciais se acerba no contexto atual, tendo em vista que a crise econômica, que assola o País desde 2015, não apresenta muitos sinais de enfraquecimento.

Observando a evolução do gasto orçamentário em relação ao total gasto com Seguridade Social, nota-se que houve uma ampliação da parcela direcionada à Assistência Social, saindo de 7\%, em 2006, para $9 \%$, em 2018. É importante sublinhar, porém, que a maior parte do gasto do orçamento da Seguridade Social é destinada à previdência social (69\% em 2018), o que torna premente o debate sobre sustentabilidade fiscal desse gasto e quais as prioridades da sociedade em relação às políticas sociais. Conforme Jesus (2019), o gasto do Regime Geral da Previdência Social é financeiramente insustentável, na medida em que o déficit da previdência está positivamente associado com a dívida previdenciária do período anterior. Se a tendência do gasto não for revertida, uma parcela cada vez maior da carga tributária terá que ser destinada a essa área em detrimento de outras, que também são meritórias. Não se quer aqui ser plenamente favorável à proposta ora em mesa de reforma da previdência, na medida em que a mesma não combate muitos dos privilégios desse sistema, mas chamar atenção para o alto gasto com essa política, o que certamente reflete no baixo gasto em outras áreas, como a assistência social.

Gráfico 4 - Representação das Funções do Governo em Relação ao Orçamento da Seguridade Social, Brasil, 2006-2018

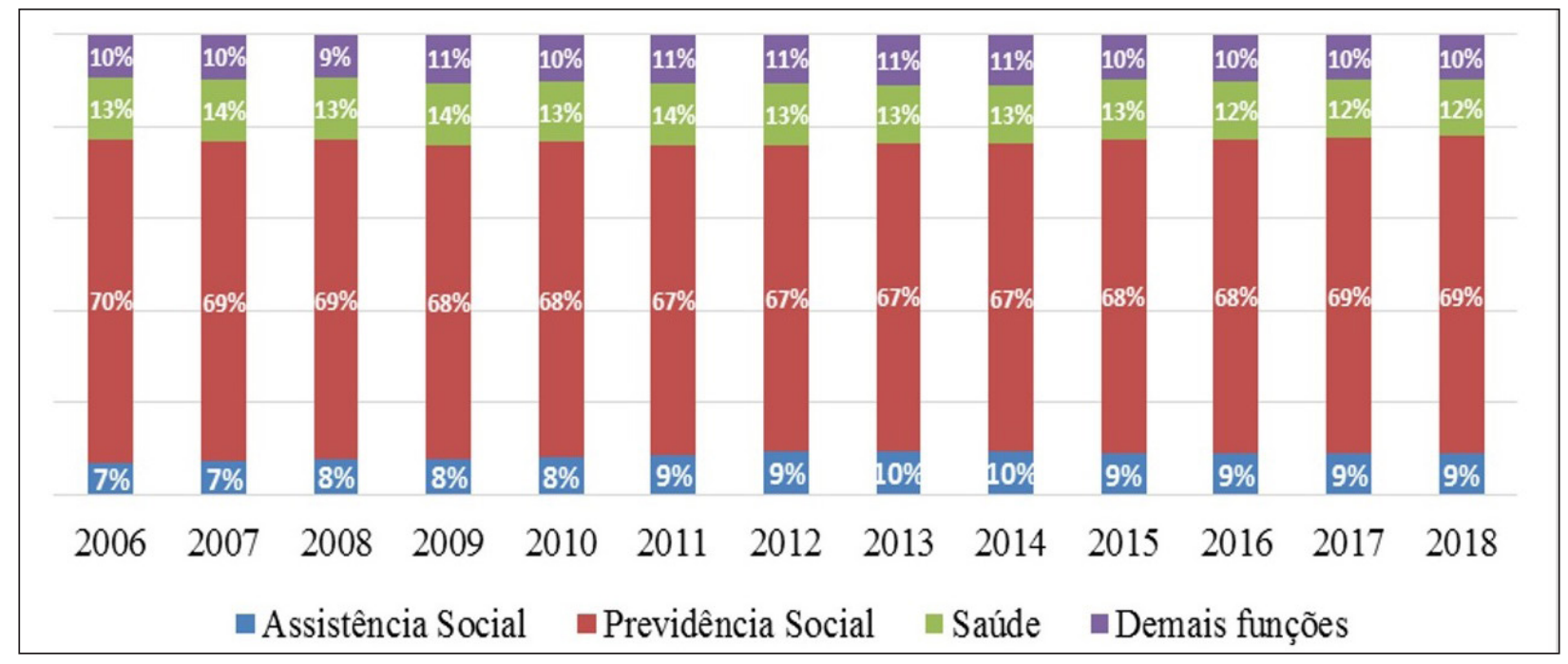

Fonte: Elaboração própria com base em SIAFI, 2006-2018.

Uma vez apresentado o panorama geral do orçamento federal da política de assistência social, é importante conceder relevo ao principal componente desse gasto, que é a transferência de renda. No período em análise, por volta de $90 \%$ dos recursos da função 8 foram destinados para o pagamento de benefícios socioassistenciais, notadamente o Bolsa Família e o Benefício de Prestação Continuada (BPC), conjuntamente com a Renda Mensal Vitalícia (RMV).

O Programa Bolsa Família é um programa de transferência de renda com condicionalidades destinado às famílias extremamente pobres e às famílias pobres com crianças e jovens. Foi instituído, em forma de lei, em 2004, sendo resultado da junção de diferentes programas. Na última década, o papel do Programa Bolsa 
Família (PBF) no campo da garantia de renda do sistema de proteção social brasileiro se robusteceu por meio de diversas iniciativas, como a ampliação da cobertura, o alcance aos invisibilizados nas ações sociais públicas, a ampliação do valor e dos critérios de elegibilidade dos benefícios, além da interlocução com outras políticas públicas, como ocorreu ao longo do Plano Brasil sem Miséria. Acompanhando a proeminência do programa no sistema de proteção social brasileiro, tem-se o aporte orçamentário, que oscilou entre 33 e $38 \%$ do orçamento da assistência social, entre 2006 e 2018, como pode ser visto no Gráfico 5. Não se sabe com segurança os motivos da queda da importância do PBF no orçamento da assistência social a partir de 2015, mas é possível aventar que deve ser proveniente do endurecimento na fiscalização e concessão do PBF no Governo Temer.

Gráfico 5 - Representação do PBF sobre a Assistência Social, Brasil, 2006-2018

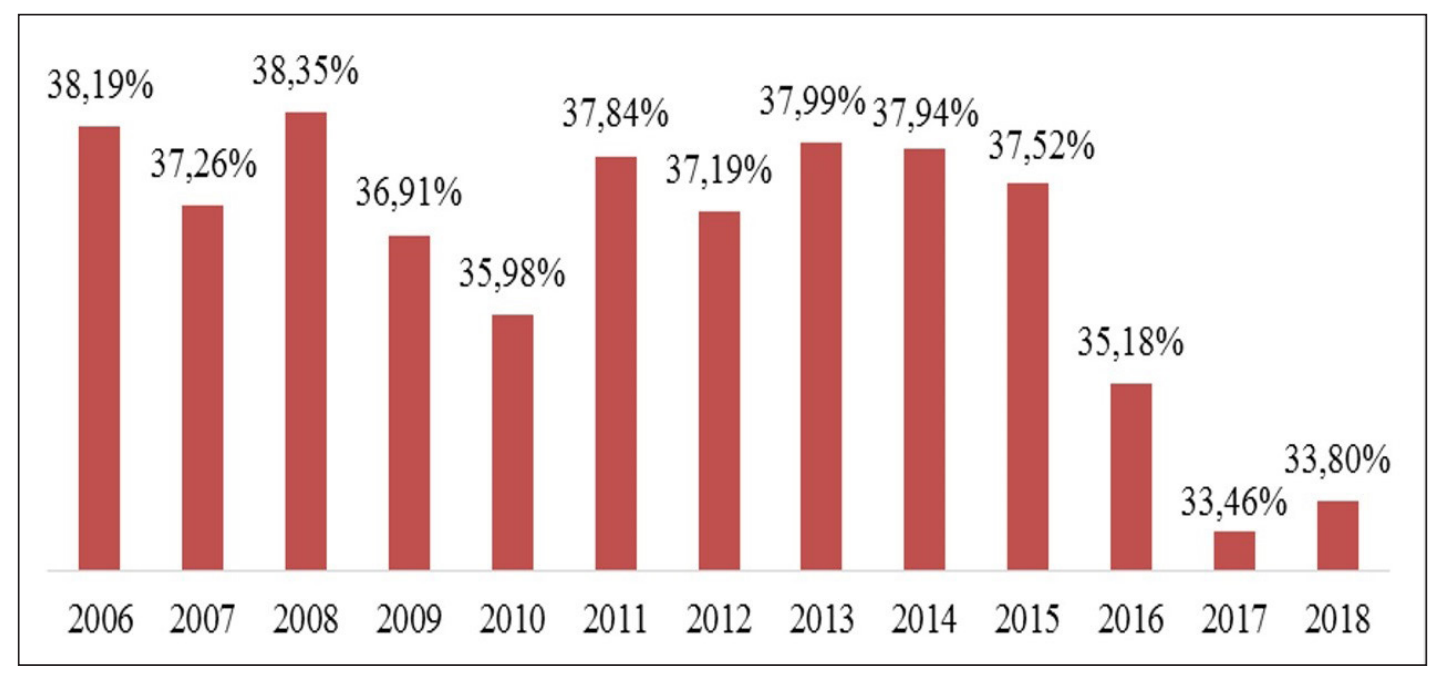

Fonte: Elaboração própria com base em SIAFI, 2006-2018.

Em termos de proporção do PIB, o gasto com o PBF saiu de um patamar de 0,34\%, em 2006, para 0,44\%, em 2018 (Gráfico 6). Embora não tenha sido um crescimento tão expressivo, foi suficiente para afiançar a trajetória aditiva do programa em termos de famílias beneficiadas e de valor do benefício.

Gráfico 6 - Representação do PBF sobre o PIB, Brasil, 2006-2018

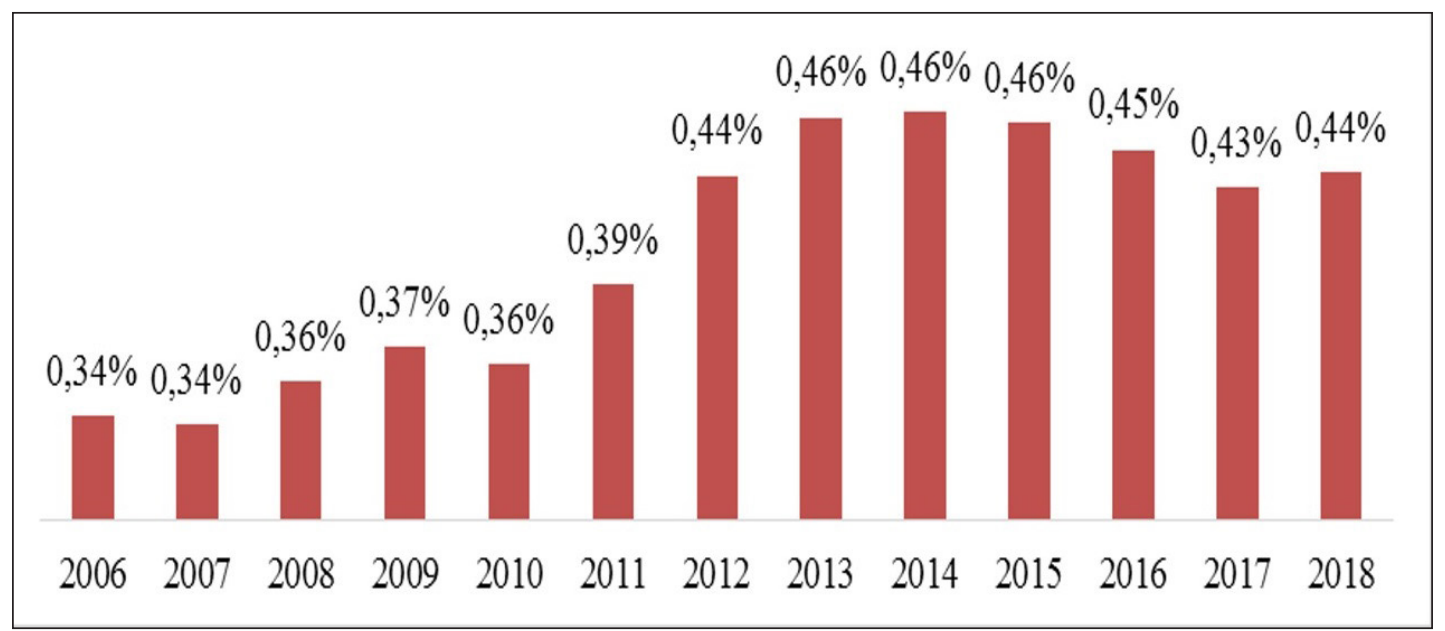

Fonte: Elaboração própria com base em SIAFI, 2006-2018. 
O Benefício de Prestação Continuada (BPC) é uma transferência mensal no valor de um salário mínimo para uma pessoa portadora de deficiência ou idosa que apresente renda familiar per capita menor que $25 \%$ do salário mínimo. Esse benefício está previsto na Constituição de 1988 e foi regulamentado pela Lei Orgânica da Assistência Social (LOAS) em 1993. Quanto ao Renda Mensal Vitalícia (RMV), é a transferência de um salário mínimo ao mês para idosos necessitados ou inválidos que tenham contribuído na previdência por ao menos 12 meses. Desde 1996, vem ocorrendo uma substituição da RMV pela BPC.

O Benefício de Prestação Continuada inaugura no Brasil a garantia de renda não contributiva, delineando um novo patamar de proteção social sob a égide do Estado. O programa promove cidadania ao afiançar, por meio da concessão de um valor monetário, melhores condições de vida para um contingente de pessoas pobres com idade avançada ou alguma deficiência física, mental ou sensorial. Para Jaccoud, Mesquita e Paiva (2017), o BPC, nas últimas décadas, tem se revelado uma transferência altamente progressiva que, justamente por beneficiar idosos e deficientes dos estratos mais pobres da população com um benefício no valor de um salário mínimo, apresenta impactos expressivos sobre a miséria e a desigualdade social no País.

Quanto à representatividade do BPC e do RMV em relação à assistência social, não há um padrão geral definido, com crescimentos e quedas ao longo da série, como mostra o Gráfico 7. Cabe notar, porém, que a proporção é elevada, tendo em vista que esses programas representam mais de $50 \%$ do orçamento da assistência social, fato que deve encontrar amparo no fato de o benefício ser no valor de 1 salário mínimo.

Gráfico 7 - Representação do BPC e RMV sobre Assistência Social, Brasil, 2006-2018

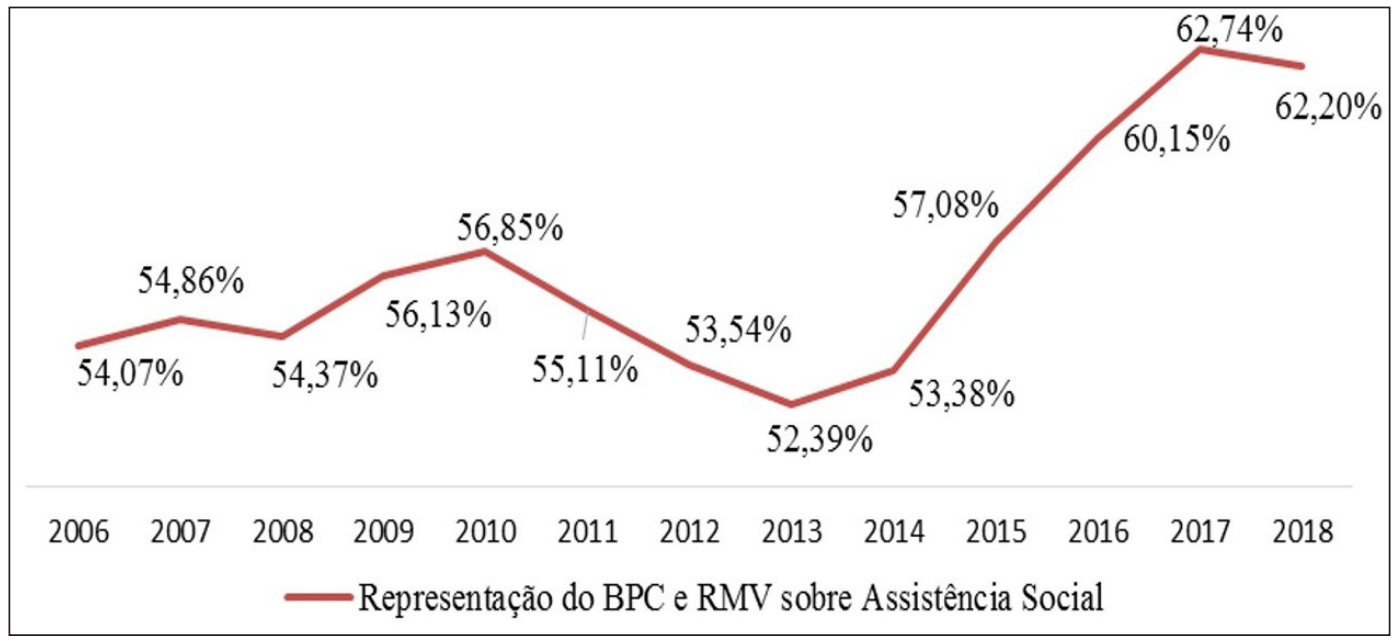

Fonte: Elaboração própria com base em SIAFI, 2006-2018.

O destaque que esses programas têm para o enfrentamento da pobreza e da desigualdade, certamente, é proveniente do fato de eles abarcarem sozinhos metade de todo o orçamento da área. Não se pretende questionar a generosidade dessa transferência, mas chamar atenção para a necessidade de maiores aportes orçamentários de modo a ter recursos suficientes para consolidar o Sistema Único de Assistência Social, que hoje ainda apresenta debilidades na qualidade e abrangência da oferta.

Olhando o gasto com BPC e RMV como proporção do PIB, a trajetória é ascendente, saindo de um patamar de $0,48 \%$, em 2006, para $0,81 \%$, em 2018. É preciso levar em consideração, contudo, que houve uma redução no crescimento do PIB brasileiro em 2009, e taxas negativas de crescimento nos anos de 2015 e 2016. 
Gráfico 8 - Representação do BPC e RMV sobre o PIB, Brasil, 2006-2018

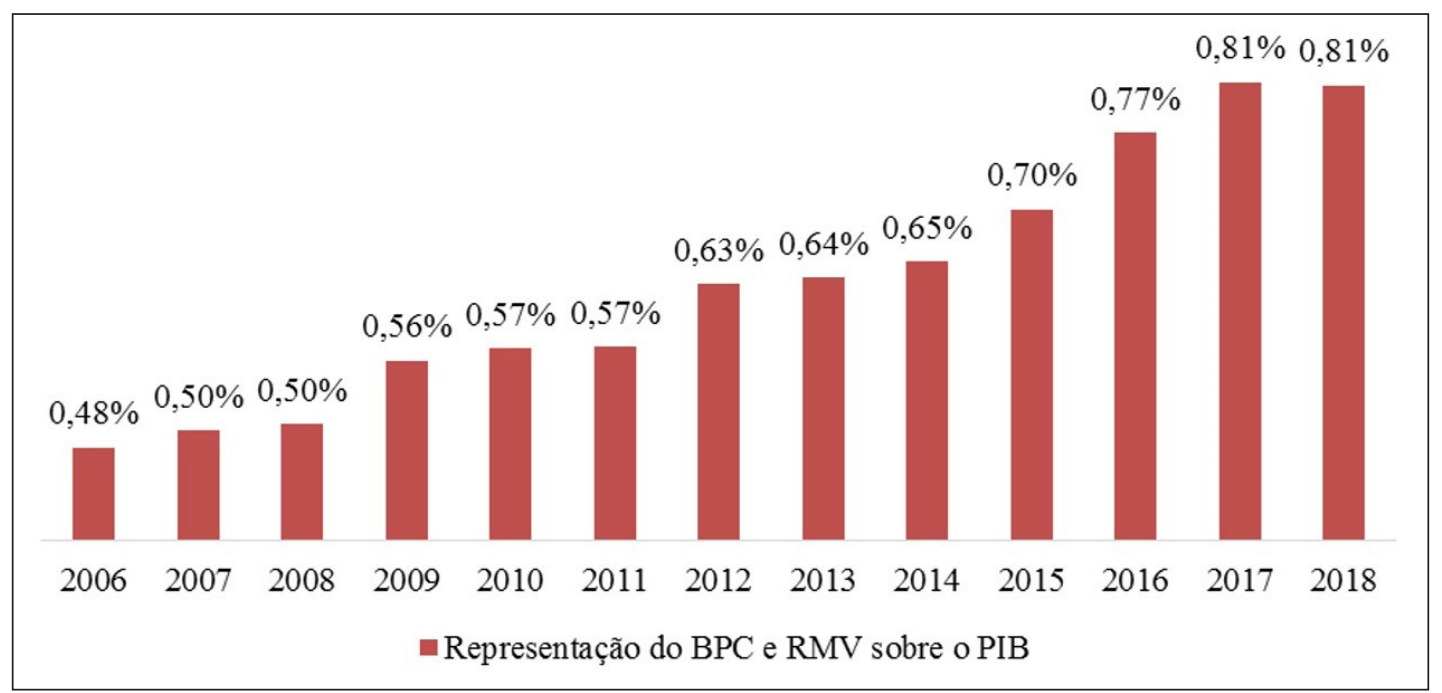

Fonte: Elaboração própria com base em SIAFI, 2006-2018.

Considerando todos os dados apresentados nesta seção, pode ser notado que houve um aumento considerável da importância dada pela União à Assistência Social no período em análise, 2006 a 2018. É importante destacar, porém, que as conclusões a serem alcançadas no final da análise não abrangem todas as informações sobre o orçamento público em assistência social ${ }^{6}$. É necessário ter em mente que houve mudanças normativas em relação ao compromisso do gasto em assistência social entre os entes federados que podem ter ocasionado variações mais específicas no aporte orçamentário. Diante disso, é premente investigações futuras que centrem a sua análise no empenho de cofinanciamento dos municípios e dos estados, de modo a traçar um panorama mais amplo do financiamento assistencial.

Por fim, cabe sublinhar que houve avanços na importância dada à Assistência Social no Brasil, porém as perspectivas são incertas quanto à manutenção deste quadro, como será destacado na próxima seção.

\section{Perspectivas para a política de assistência social}

Como mostrado na seção anterior, nos últimos anos houve um notório esforço em consolidar a assistência social enquanto política pública. O caminho trilhado conduziu ao adensamento da institucionalidade, à maior abrangência territorial e populacional, e à ampliação do escopo protetivo da política. Todavia, o cenário atual, de crise econômica conjugada à crise política, desponta incertezas em relação aos rumos que, a partir de então, marcarão a área assistencial.

Cabe comentar, brevemente, dois elementos que suscitam preocupações e que auxiliam na discussão sobre o futuro da política de assistência social. Com teor mais micro, o primeiro elemento refere-se a uma provável guinada na concepção de assistência social. O segundo, de amplitude macro, concerne ao Novo Regime Fiscal.

A área assistencial, de longa data, foi marcada por práticas vinculadas à caridade e à benemerência. Cotidianamente, as ações assistenciais eram desempenhadas de acordo com princípios religiosos da tradição cristã, com foco em um atendimento emergencial a pessoas em situação de vulnerabilidade.

Com a Constituição de 1988, se delineia uma nova concepção para assistência social, que passa a ser considerada um direito de cidadania. Embora a Carta Magna preveja a assistência como direito, o 
cumprimento desse compromisso do Estado se deu muito paulatinamente até os anos 2000, e de modo mais acelerado a partir de 2004, com a promulgação da PNAS, e posteriormente a NOB, que regulamentou o SUAS.

Desde 2004, foi se consolidando, de modo institucional, a concepção de assistência social como direito. Nesse caminho, houve mudanças tanto no trato ao público atendido dado à concepção de cidadania operante, como na construção da política, que passou a ser realizada de modo democrático nas instâncias deliberativas, CIT e CNAS. Todavia, a mudança de presidente, em 2016, com o afastamento da presidente Dilma Rousseff no processo de impeachment, deu uma nova tônica para a área assistencial.

A primeira ação de destaque na área realizada pelo presidente Temer foi a criação do "Programa Criança Feliz". A forma como foi lançado e concebido esse programa permite aventar um novo tom para a assistência em dois aspectos: i) na concepção de assistência que pareceria orientar o programa; e ii) no processo institucional de elaboração dele.

Em relação ao primeiro aspecto, ganhou projeção nacional o questionamento em relação ao retorno do primeiro damismo no Brasil, dado que a então Primeira Dama - Marcela Temer - não apenas foi quem lançou o programa, com um discurso conservador em relação ao papel da mulher e a concepção de assistência social, como foi tida a embaixatriz do programa. A imagem de Marcela Temer, meiga, recatada e do lar, que de modo voluntário trabalharia em prol do "Programa Criança Feliz", remonta, dada a semelhança de concepção, ao comando da Legião Brasileira de Assistência Social (LBA), pela então Primeira Dama Darcy Vargas.

O período que a LBA esteve à frente da organização das ações assistenciais pode ser considerado como um momento de primeiro damismo no Brasil, dado que as primeiras damas eram sempre as responsáveis pelo comando da LBA. As ações da LBA eram orientadas por princípios de filantropia e benemerência, com uma oferta socioprotetiva residual e emergencial, o que concede ao momento "primeiro damismo na assistência" uma tônica bem distinta da concepção das ações assistenciais como direito de cidadania. Não causa estranheza, portanto, a reação negativa dos especialistas da área e dos militantes à imagem do Criança Feliz vinculada à Primeira Dama Marcela Temer. Embora não se tenha elementos para afirmar a real intenção, o gesto sinalizava a possibilidade de retorno do primeiro damismo no País e a concepção inerente a ele da assistência como caridade e benesse. O discurso meritocrático do então eleito presidente Jair Bolsonaro sugere que essa tônica será mantida nos próximos anos no Brasil.

Em relação ao segundo aspecto, chama atenção a forma que foi gestado o Criança Feliz. Nos últimos anos, as ações na área da assistência têm sido debatidas e construídas nas instâncias de deliberação da política, CIT e CNAS, que contam com a participação do governo e da sociedade civil. São nesses espaços democráticos que vêm se concretizando a promoção do direito à assistência social. Todavia, além da polêmica que cerca o Criança Feliz por causa da menção ao primeiro damismo, o programa também desrespeitou o caminho que até então tem sido seguido para a construção de ações na área assistencial. O Criança Feliz foi lançado sem uma prévia discussão na CIT e no CNAS, muito menos com a deliberação por essas instâncias desse programa, que aparentava ser o carro chefe do governo Temer na área. Posteriormente à criação de fato do programa é que ele se tornou foco das discussões na CIT e CNAS, sendo "aceito" no SUAS após muita resistência.

Os dois fatos levantados permitiram suspeitar de uma nova orientação para a área assistencial no governo Temer, com tendências de prosseguimento no governo Bolsonaro, e ao que parece com uma concepção oposta à trajetória seguida até então. Se, como sinalizado, de fato for enfraquecida a concepção da assistência enquanto direito a favor da ideia de caridade, é provável que se mitiguem os esforços galgados na construção do SUAS. Portanto, por esse ângulo as perspectivas são de mitigação ou reversão do crescimento dos aportes orçamentários para manutenção, construção e ampliação da rede socioprotetiva.

O elemento de teor macro que suscita preocupação é a instituição do Novo Regime Fiscal (NRF). Aprovado em 26 de outubro de 2016, a Proposta de Emenda à Constituição (PEC) 241, na Câmara dos Deputados, renomeada no Senado Federal como PEC 55, instituiu o Novo Regime Fiscal no Brasil para os próximos vinte anos, com possibilidade de revisão apenas no décimo ano. 
A proposição do NRF é que a despesa primária da União seja limitada ao gasto realizado no ano de 2016, sendo esse apenas corrigido anualmente pela variação do Índice Nacional de Preços ao Consumidor Amplo (IPCA) até 2036.

Autores críticos ao NRF, Azevedo (2016), Amaral (2016), Rossi e Dweck (2016), Vieira e Benevides (2016) e Paiva et al. (2016), apontam que, na prática, esse novo regime representa o "congelamento", em termos reais, no valor de 2016, das despesas primárias da União por 20 anos. Para esses autores, o NRF é uma dura proposta de austeridade fiscal, com potenciais diminutos de promover crescimento econômico, e com efeitos de mitigação dos gastos na área social.

Amaral (2016) e Azevedo (2016) chamam atenção para o fato de que o NRF estabelece um patamar limítrofe de gastos que não considera a dívida pública, ficando assim financistas protegidos do "congelamento" orçamentário. Para Rossi e Dweck (2016), a reforma fiscal aparenta ser muito mais um projeto de redução do tamanho do Estado, do que um plano de estabilização de longo prazo.

Defensores como Almeida (2016) negam que o NRF irá promover o congelamento das despesas primárias por 20 anos. Para o autor, a proposta é que, ao longo dos próximos dez anos, a despesa primária do governo central tenha crescimento próximo de "zero", o que representa um ajuste fiscal gradual. Mendes (2016) aponta que o NRF atacará a causa fundamental do problema fiscal - o crescimento acelerado do gasto -, o que permitirá a acomodação do desajuste que a economia enfrenta. Para o autor, a população de baixa renda será a beneficiária do ajuste fiscal, uma vez que são esses os maiores prejudicados com o baixo desempenho da economia e não são hoje os ganhadores do gasto público. Camargo e Gamerman (2016) consideram que o teto para as despesas primárias é a legislação mais importante, em termos econômicos, desde o Plano Real. Para os autores, o NRF não congela o gasto social, apenas estabelece que o aumento em uma área deva ser compensando pela redução em outra, ou seja, os parlamentares terão que definir prioridades na alocação do orçamento.

Aparentemente, críticos e apoiadores do NRF apresentam preocupações e anseios distintos. O primeiro grupo centra a sua atenção na questão dos impactos sociais que o regime poderá ocasionar; já para o segundo grupo, a necessidade de ajuste fiscal que se encontra em relevo.

Não se quer aqui discordar da necessidade de melhorar as contas públicas e de promover o crescimento da economia, todavia, o caminho seguido não parece atender a essa demanda, podendo até mesmo apresentar efeitos reversos. O futuro, provavelmente, confirmará os receios que cercam o NRF.

Enquanto isso, cabe sinalizar as perdas potenciais na área da assistência social dado o NRF. Os dados de Paiva et al., (2016) revelam uma distância, com comportamento crescente, entre o gasto projetado para o Cenário Base, que reflete o gasto com a política de assistência nos moldes atuais, e o gasto projetado considerando o Cenário NRF. A perda de financiamento da assistência, em 10 anos, seria de R\$ 199 bilhões, e, em 20 anos, totalizaria R\$ 868 bilhões.

Em que pese o NRF não estabelecer como deve ser acomodado o teto dos gastos primários, as estimativas de Paiva et al., (2016) já revelam que, se a escolha for de cada Ministério ter as suas despesas corrigidas pelo IPCA, conforme os gastos do ano de 2016, o não crescimento real dos gastos assistenciais inviabilizará a manutenção da oferta socioprotetiva de hoje.

Os dados orçamentários de 2017 e 2018, felizmente, ainda não apontam para reversão da trajetória crescente de investimento nessa área, sendo, certamente, os gastos reduzidos em outras políticas sociais. Cabe sublinhar, porém, que o cenário futuro é de elevação da demanda assistencial tanto devido aos efeitos deletérios da crise econômica como do contexto de envelhecimento populacional, sendo premente a necessidade de aportes orçamentários crescentes para a área.

Cabe ponderar que mais de uma década de SUAS e de Bolsa Família, certamente, ascenderam o patamar de proteção social brasileira. Todavia, os avanços recentes, apesar de muitos, foram insuficientes para afiançar um padrão elevado de bem-estar e de segurança à população mais vulnerável.

As perspectivas para a política de assistência, e para as políticas sociais de modo geral, são pouco animadoras, dado que com o NRF há um risco premente de estagnação, ou até mesmo de descontinuidade e retrocesso na oferta socioassistencial. 
Por fim, cabe mencionar as propostas do novo governo brasileiro que devem impactar o orçamento e a oferta socioassistencial. Nos primeiros meses do governo de Jair Bolsonaro, eleito presidente em 2018, as propostas de mudanças nos benefícios sociais já estão se desenhando. Bolsonaro e a sua equipe de governo já anunciaram a proposta que modifica o sistema de previdência social, estabelece regras de transição e disposições transitórias e dá outras providências, como a criação de regras diferenciadas para o atual público do Benefício de Prestação Continuada, cuja principal mudança proposta é o não atrelamento do valor do pagamento ao salário mínimo (BRASIL, 2019).

A reforma da previdência ainda está em discussão, podendo haver mudanças, porém, notoriamente ela trará consequências para a oferta socioprotetiva brasileira. A proposta inicial era que as pessoas em miserabilidade, que não tenham conseguido contribuir para a previdência pelo tempo mínimo durante sua vida e que hoje recebem um salário mínimo a partir dos 65 anos, passariam a receber $R \$ 400,00$ a partir dos 60 anos de idade. Só a partir dos 70 anos, o beneficiário receberia um salário mínimo completo. Essa proposta, porém, já foi retirada da primeira versão do relatório na Comissão Especial. Inclui, todavia, medida para combater fraudes, com detalhamento na composição de renda familiar per capita de até 1/4 do salário mínimo a partir dos 65 anos para ter direito ao benefício (a aprovação ainda está em tramitação - tendo como base julho de 2019).

O BPC já tinha sido alvo da proposta de reforma previdenciária do governo Temer, com proposições, tais como a elevação de 65 para 70 anos como idade mínima para receber o benefício e a desvinculação ao valor do salário mínimo (ainda não tinham entrado em acordo sobre o valor). É importante destacar que a redução do BPC para um valor menor do que um salário mínimo retira a garantia de renda mínima para as necessidades básicas de subsistência aos idosos (e deficientes) em condição de miserabilidade. A implementação do BPC nas últimas décadas trouxe impactos progressivos na redução da miséria, como demonstram Medeiros, Melchior e Granja (2009) em suas pesquisas, tendo em vista que esses benefícios alcançam os grupos de renda mais baixa da população, impactando na pobreza e na desigualdade de renda. O BPC, portanto, é importante não só pela transferência de renda aos mais necessitados, impactando diretamente sobre os índices ainda alarmantes como pobreza e desigualdade de renda, mas, também, porque o seu valor ser de um salário mínimo, intensifica o seu impacto positivo para a população necessitada.

Se a proposta de reforma previdenciária, em discussão no senado federal, aprovar alterações que impactem negativamente sobre esse benefício, o resultado será o aumento da desproteção social, não só dos idosos e pessoas pobres incapacitadas ao trabalho, como de seus familiares. A redução do valor do benefício, ou o aumento das restrições para participação de idosos e deficientes, podem reduzir os impactos de garantia de renda para os beneficiários, tendo em vista que o salário mínimo é um valor aproximado para suprir as necessidades mínimas de um trabalhador, apesar de ainda existirem pesquisas que considerem esse valor inferior a esse "mínimo". A depender do que for aprovado, essa reforma previdenciária poderá comprometer os principais elementos e princípios de equidade na seguridade social, podendo, como consequência, reduzir os efeitos positivos que a ampliação desses benefícios sociais vinha trazendo nos últimos anos.

\section{Considerações finais}

No período recente, a política de assistência vem passando por um notório processo de construção e aprimoramento, em sintonia com a consolidação do Sistema Único de Assistência Social. Após uma longa trajetória de diminuta atuação pública, a área tem sido alvo de diversas iniciativas que têm proporcionado a travessia da assistência do campo da caridade e benemerência para o do direito, que deve ser garantido pelo Estado.

Os caminhos trilhados, a partir da Constituição de 1988, conduziram ao adensamento da institucionalidade da política assistencial, tendo como principais regulamentações: a Política Nacional de Assistência Social; a Lei Orgânica da Assistência Social; a Norma Operacional Básica da Assistência Social; e a Lei do SUAS. Essas normativas possibilitaram a construção da área enquanto política pública, atuando em todo território nacional. 
O avanço da primazia estatal demandava um padrão de financiamento distinto da lógica per capita, em conformidade com a série histórica de repasses nos valores dos convênios firmados pela LBA, que disciplinou as ações assistenciais até a construção do SUAS. A partir das diretrizes da PNAS, o financiamento passa a ocorrer tendo como foco o serviço a ser estruturado no território nacional, quebrando com a lógica genérica que orientava uma provisão pontual e sem a devida proteção estatal às famílias vulnerabilizadas.

Em conformidade com um sistema descentralizado, participativo e territorializado, como é o SUAS, o financiamento passou a ser operado na forma de pisos de proteção afiançadores de uma oferta socioassistencial continuada. $\mathrm{O}$ novo padrão de financiamento concede relevo à responsabilidade compartilhada entre os entes federados, instituindo o cofinanciamento das ações assistenciais.

Conquistas notórias foram presenciadas na formulação do financiamento da política de assistência social, com destaque para: i) estabelecimento dos fundos de assistência social; ii) estruturação de pisos de proteção e blocos de financiamento; iii) modalidade de transferência fundo a fundo, com regularidade; iv) partilha de recursos pactuada de modo democrático e observando as peculiaridades territoriais; e v) cofinanciamento entre os três entes federados.

Hoje há um amplo leque de normativas que, em termos práticos, materializam o amadurecimento do financiamento da política de assistência social desde a sua consagração, em 1988, enquanto política pública, e o estabelecimento de um sistema único operando em todo território nacional.

O avanço dos aportes orçamentários foi se impondo em sintonia com a promoção do direito à assistência social, sendo que, entre 2006 e 2018, presenciou-se um aumento real de R\$ 46, 6 bilhões na função 8 do orçamento federal. E, como proporção do PIB, o aumento entre 2006 e 2018, do orçamento assistencial, foi da ordem de 0,4 ponto percentual.

Muitos desafios, todavia, ainda comparecem na consolidação do SUAS. Em que pese à capilaridade galgada pela política assistencial no período recente, ainda parecem persistir os problemas de qualidade e de estruturação da rede de atenção socioassistencial, que comprometem a efetividade da oferta socioprotetiva. Embora entre 2006 e 2018 tenha havido um crescimento do orçamento federal para a Assistência Social, a proporção do gasto federal na estruturação da rede e da oferta de serviços ainda é incipiente frente aos dispêndios com transferência de renda que ocuparam, em toda série, quase $90 \%$ dos gastos assistenciais.

É importante salientar que, a expressividade dos avanços, em termos de garantia de renda à população pauperizada, teve papel proeminente no enfrentamento da pobreza e da promoção da cidadania inclusiva, o que faz do direcionamento dos recursos assistenciais uma escolha acertada. Daqui em diante aportes adicionais deveriam ser direcionados à área, de modo a possibilitar a efetivação do Sistema Único de Assistência Social.

O cenário prospectivo, porém, não é nada favorável, já que há sinalizações do governo atual de enfraquecimento da área enquanto política pública e a imposição de um Novo Regime Fiscal que comprimirá todos os gastos sociais.

\section{Referências}

ALMEIDA, Mansueto. Esclarecimentos sobre a PEC 241. Valor econômico de 14 de outubro de 2016. 2016. Disponível em: https://www.valor.com.br/opiniao/4743709/esclarecimentos-sobre-pec-241. Acessado em: 08 nov. 2016.

AMARAL, Nelson Cardoso. PEC 241/55: a "morte" do PNE (2014-2024) e o poder de diminuição dos recursos educacionais. RBPAE, v. 32, n. 3, p. 653 - 673 set./dez. 2016. Disponível em: https://seer.ufrgs.br/rbpae/article/view/70262. Acessado em: 12 fev. 2017. https://doi.org/10.21573/vol32n32016.70262

AZEVEDO, Mario Luis Neves. O Novo Regime Fiscal: a retórica da intransigência, o constrangimento da oferta de bens públicos e o comportamento do PNE 2014-2024. Tópicos Educacionais, Recife, v. 22, n. 1, p. 236-259, jan./jun., 2016. Disponível em: https://periodicos.ufpe.br/revistas/topicoseducacionais/article/view/22442. Acesso em: 05 abr. 2017.

BRASIL. Ministério do Desenvolvimento Social e Combate à Fome - MDS. Secretaria Nacional de Assistência Social - SNAS. Política Nacional de Assistência Social. Brasília, 2004. Disponível em: https://www.mds.gov.br/webarquivos/publicacao/ assistencia_social/Normativas/PNAS2004.pdf. Acesso em: 16 nov. 2017. 
BRASIL. Norma Operacional Básica - NOB/SUAS, aprovada pelo Conselho Nacional de Assistência Social por intermédio da Resolução no 130. Brasília, 2005. Disponível em: http://www.mds.gov.br/cnas/legislacao/resolucoes/arquivos-2005/ CNAS\%202005\%20-\%20130\%20-\%2015.07.2005.doc. Acesso em: 30 nov. 2017.

BRASIL. Câmara dos Deputados. Proposta de Emenda à Constituição (PEC) - em tramitação. Versão de 28.01.2019. Modifica o sistema de previdência social estabelece regras de transição e disposições transitórias, e dá outras providências. Disponível em: https://www.camara.leg.br/proposicoesWeb/fichadetramitacao?idProposicao=2192459. Acesso em: 17 fev. 2019.

CAMARGO, José Marcio; GAMERMAN, André. Mitos e verdades sobre a PEC 241. O Globo, 19 de outubro de 2016. 2016. Disponível em: https://oglobo.globo.com/economia/artigo-mitos-verdades-sobre-pec-241-20312217. Acessado em: 5 nov. 2016.

COLIN, Denise. Sistema de gestão e financiamento da assistência social: transitando entre a filantropia e a política pública. Tese (Doutorado em Ciências Sociais) - Universidade Federal do Paraná, Curitiba. 2008. Disponível em: https:// acervodigital.ufpr.br/bitstream/handle/1884/17500/Texto\%20final\%20tese\%20corrigido.pdf?sequence=1\&isAllowed=y. Acesso em: 15 set. 2017.

IBGE. Síntese de indicadores sociais: uma análise das condições de vida da população brasileira: 2018 / IBGE, Coordenação de População e Indicadores Sociais. Rio de Janeiro: IBGE, 2018. 151 p. Disponível em: https://biblioteca.ibge.gov.br/ visualizacao/livros/liv101629.pdf. Acesso em: 10 jan. 2019.

JACCOUD, Luciana de Barros; MESQUITA, Ana Cleusa Serra; PAIVA, Andrea Barreto. O Benefício de Prestação Continuada na reforma da previdência: contribuições para o debate. Rio de Janeiro: Ipea, 2017. (Texto para Discussão, n. 2301). Disponível em: http://www.social.mg.gov.br/images/documentos/capacita_suas/textos_complementares/BPC_reforma.pdf. Acesso em: 20 jan. 2018.

JESUS, Cleiton Silva. Transição Demográfica e o Regime Gral da Previdência Social no Brasil. 2019 (No prelo).

MEDEIROS, M.; MELCHIOR, S. N.; GRANJA, H. F. A distribuição das transferências, público-alvo e cobertura do benefício de prestação continuada (BPC). Revista Textos \& Contextos, Porto Alegre, v. 8, n. 2, p. 358-376, jul./dez. 2009. Disponível em: http://revistaseletronicas.pucrs.br/ojs/index.php/fass/article/viewFile/6350/4649. Acessado em: 05 fev. 2019.

MENDES, Marcos. O teto de gastos e a proteção aos pobres. Folha de São Paulo, 25 de setembro de 2016. 2016. Disponível em: https://www1.folha.uol.com.br/ilustrissima/2016/09/1815978-o-teto-de-gastos-e-a-protecao-aos-pobres.shtml. Acesso em: 30 out. 2016.

MENDES, Áquilas. O fundo público e os impasses do financiamento da saúde universal brasileira. Saúde e Sociedade (USP), São Paulo, v. 23, p. 1183-1197, 2014. Disponível em: http://www.scielo.br/pdf/sausoc/v23n4/0104-1290-sausoc-23-4-1183. pdf. Acesso em: 12 abr. 2019. https://doi.org/10.1590/s0104-12902014000400006

MESQUITA, Ana Cleusa; MARTINS, Raquel de Fátima; CRUZ, Tânia Mara Eller. Cofinanciamento e responsabilidade federativa na política de assistência social. Rio de Janeiro: Ipea, 2012. (Texto de Discussão no 1724). Disponível em: http:// www.ipea.gov.br/portal/images/stories/PDFs/TDs/td_1724.pdf. Acessado em: 10 jul. 2018.

PAIVA; Andrea Barreto; MESQUITA, Ana Cleusa Serra; JACCOUD, Luciana; PASSOS, Luana. O Novo Regime Fiscal e suas implicações para a política de Assistência Social no Brasil. Brasília: Ipea, 2016. (Nota Técnica Ipea no 27). Disponível em: http://www.ipea.gov.br/portal/images/stories/PDFs/nota_tecnica/160920_nt_27_disoc.pdf. Acesso em: 03 mar. 2017. RIBEIRO, Isabela; SALVADOR, Evilasio. Hegemonia e políticas sociais no Brasil: contribuições ao debate sobre vinculação orçamentária. Revista Katalysis, Florianópolis, v. 21, p. 76-85, 2018. Disponível em: https://periodicos.ufsc.br/index.php/ katalysis/article/view/1982-02592018v21n1p76. Acesso em: 12 abr. 2019. https://doi.org/10.1590/1982-02592018v21n1p76

ROSSI, Pedro; DWECK, Esther. Impactos do Novo Regime Fiscal na saúde e educação. Cad. Saúde Pública, Rio de Janeiro, v. 32, n. 12, p. 1-5, 2016. Disponível em: http://www.scielo.br/pdf/csp/v32n12/1678-4464-csp-32-12-e00194316.pdf. Acesso em: 15 dez. 2016. https://doi.org/10.1590/0102-311x00194316

SALVADOR, Evilasio. Fundo Público e Financiamento das Políticas Sociais no Brasil. Serviço Social em Revista (Online), Londrina, v. 14, p. 4-22, 2012. Disponível em: http://www.uel.br/revistas/uel/index.php/ssrevista/article/view/12263. Acesso em: 13 abr. 2019. https://doi.org/10.5433/1679-4842.2012v14n2p4

SPOSATI, Aldaiza. Descaminhos da seguridade social e desproteção social no Brasil. Ciencia \& Saude Coletiva, Rio de Janeiro, v. 23, p. 2315-2325, 2018. Disponível em: http://www.scielo.br/pdf/csc/v23n7/1413-8123-csc-23-07-2315.pdf. Acesso em: 12 de abril de 2019. https://doi.org/10.1590/1413-81232018237.10202018 
TAVARES, Gisele de Cássia. O financiamento da política de assistência social na era Suas. In: MDS; UNESCO. (org.). Concepção e gestão da proteção social não contributiva no Brasil. Brasília: MDS, 2009. p. 229-254. Disponível em: https://www.mds.gov.br/webarquivos/publicacao/assistencia_social/Livros/concepcao_gestao_protecaosocial.pdf. Acesso em: 20 maio 2017.

TAVARES, Gisele de Cássia. O financiamento no SUAS e as condições para efetivação dos direitos socioassistenciais. In: COLIN, D.; CRUS, J.; TAPAJÓS, L.; ALBUQUERQUE, S. (org.). Vinte anos da Lei Orgânica da Assistência Social. Brasília: MDS, 2013. p. 170-187. Disponível em: http://www.mds.gov.br/webarquivos/publicacao/assistencia_social/ Livros/20anosLOAS.pdf. Acesso em: 02 set. 2017.

VIEIRA, Fabíola Sulpino; BENEVIDES, Rodrigo Puci Sá. Os impactos do Novo Regime Fiscal para o financiamento do Sistema Único de Saúde e para a efetivação do direito à saúde no Brasil. Brasília: Ipea, 2016. (Nota Técnica Ipea, no 28). Disponível em: http://www.ipea.gov.br/portal/images/stories/PDFs/nota_tecnica/160920_nt_28_disoc.pdf. Acesso em: 10 dez. 2016.

\section{Notas}

${ }^{1}$ Os dados podem ser encontrados em: https://www1.siop.planejamento.gov.br/QvAJAXZfc/opendoc.htm?document=IAS\%2FExecucao_ Orcamentaria.qvw\&host=QVS\%40pqlk04\&anonymous=true. Acesso em: 15 fev. 2019.

2 Valores corrigidos pelo IPCA.

${ }^{3}$ Os benefícios eventuais deveriam ser cofinanciados pelos estados e municípios, mas até 2016 o compromisso assumido pelos estados foi diminuto, sendo objeto de intensas discussões na CIT esse tema.

${ }^{4}$ A portaria no 113, de 10 de dezembro de 2015 regulamenta o cofinanciamento federal do SUAS e as transferências de recursos na modalidade fundo a fundo.

${ }^{5}$ A ausência de informações publicizadas, de modo sistemático, sobre os aportes orçamentários dos governos estaduais e municipais na área da assistência impossibilita traçar um panorama completo do gasto nessa área.

${ }^{6}$ Dada as dificuldades de obtenção de informações sistematizadas sobre os aportes municipais e estaduais na área, foram utilizadas apenas as informações do gasto federal.

Recebido em: 8/3/2019.

Aprovado em: 25/9/2019.

Publicado em: 10/10/2019.

Endereço para correspondência:

Luana Passos de Souza

Universidade Federal de Minas Gerais

Av. Pres. Antônio Carlos, 6627 - Pampulha

31270-901, Belo Horizonte, MG, Brasil

\section{Autores:}

LUANA PASSOS DE SOUZA

Doutora em Economia pela Universidade Federal Fluminense.

Residente pós-doutoral na demografia da Universidade Federal de Minas Gerais (UFMG), Belo

Horizonte, MG, Brasil.

Orcid: https://orcid.org/0000-0002-5470-7349

E-mail: luanapassos_s@hotmail.com

ANDREIA ANDRADE DOS SANTOS

Mestre em Economia pela Universidade Federal da Bahia (UFBA), Salvador, BA, Brasil.

Assessora de monitoria e avaliação na Fundação Luís Eduardo Magalhães (FLEM), Salvador, BA, Brasil.

Doutoranda em Economia pela Universidade Federal da Bahia (UFBA), Salvador, BA, Brasil.

Orcid: https://orcid.org/0000-0001-8650-2623

E-mail: andreiaandradeds@gmail.com

Endereço: Universidade Federal da Bahia

Av. Adhemar de Barros, s/n - Ondina - 40170-110, Salvador, BA, Brasil

ALAN SCARPARI

Mestre em Economia pela Universidade Federal Fluminense (UFF), Niterói, RJ, Brasil.

Economista no Ministério da Agricultura, Pecuária e Abastecimento (MAPA), Brasília, DF, Brasil. Orcid:

https://orcid.org/0000-0003-4584-6846

E-mail: alan scarpari@hotmail.com

Endereço: Ministério da Agricultura, Pecuária e Abastecimento

Esplanada dos Ministérios - Bloco D - 70043-900, Brasília, DF, Brasil 